UDC 378.147:33-051]:004(477)

DOI: $10.31470 / 2415-3729-2018-8-151-166$

\title{
Analysis of the Experience of Applying Information and Communication Technologies in Future Economists' Professional Training in Ukraine
}

\section{Viacheslav Osadchyi}

Doctor in Pedagogy, Professor

Professor of the Department of Informatics and Cybernetics, Bohdan Khmelnytstky Melitopol State Pedagogical University $\triangle 20$, Hetmanska Str., Melitopol, Zaporizhzhia region, Ukraine, 72312 E-mail: osadchyi@mdpu.org.ua ORCID: 0000-0001-5659-4774 Article accepted for publication: November 25, 2018

\section{Аналіз досвіду застосування інформаційно- комунікаційних технологій у професійній підготовці майбутніх економістів в Украӥні}

\section{В'ячеслав Володимирович Осадчий}

доктор педагогічних наук, професор

професор кафедри інформатики і кібернетики

Мелітопольський державний педагогічний університет імені Богдана Хмельницького,

$\triangle$ вул. Гетьманська, 20, м. Мелітополь Запорізька обл., Україна, 72312

Дата надходження статті: 03 серпня 2018 р. Стаття прийнята до друку: 25 листопада 2018 р.

\section{Abstract}

The development of information technologies affects the process of professional training of specialists from different fields. 
During the last five years, scientists of Ukraine conducted a series of studies on the implementation of information and communication technologies (ICT) in professional training. The purpose of the study was to analyze the experience of applying information and communication technologies in the training of future economists, in particular, in higher education establishments (HEE) of I-II levels of accreditation in Ukraine. In the course of the research, an analysis of the availability of scientific publications on the topic was carried out on the basis of the data taken from the web portal of the V. I. Vernadskyi National Library of Ukraine and a free search engine with full texts of scientific publications at the Google Academy. As a result, 6457 relevant documents were found, which were filtered according to the following criteria: the relevance of the research topic, the implementation of the publication in the form of scientific research (article, abstract, dissertation), the publication date (from 2014 to 2019), the significance of research and significance of the results. On the basis of the publications' analysis, the following conclusions were made by the author: the relevance of understanding the results of the information and communication technologies' implementation in professional training does not decrease the training of future economists; the greatest research is devoted to the analysis of experience and clarification of the information and communication technologies' role in the future economists' training in higher education establishments of the III-IV level of accreditation; the scientific works on the ICT implementation in the HEE of the I-II level of accreditation in professional training students of economic specialties cover some aspects of this problem (the future economists' training for their professional activity through ICT; the ICT as a means of forming the future junior specialists' professional skills in the economic field in the process of studying professional disciplines; the ICT in support of future specialists' interactive training in economic specialties; the formation of key competencies of future accountants on registration of accounting data by means of the ICT).

Key words: information and communication technologies, training, future economists. 


\section{References}

1. Basarab, V. Ya. (2016). Formuvannia kliuchovykh kompetentnostei maibutnikh oblikovtsiv z reiestratsii bukhhalterskykh danykh u profesiino-tekhnichnykh navchalnykh zakladakh [Formation of key competencies of future accountants for the registration of accounting data in vocational schools]. Candidate's thesis. Kryvyi Rih : DVNZ «Kryvorizkyi natsionalnyi universytet» [in Ukrainian].

2. Havrutenko, L. A. (2017). Formuvannia profesiinykh umin maibutnikh molodshykh spetsialistiv ekonomichnoho profiliu $\mathrm{u}$ protsesi vyvchennia fakhovykh dystsyplin [Formation of professional skills for future junior specialists of economic profile in the process of studying professional disciplines] Candidate's thesis. Kyiv : Natsionalnyi aviatsiinyi universytet [in Ukrainian].

3. Dudka, U. T. (2018). Strukturno-orhanizatsiina model pidhotovky maibutnikh ekonomistiv $\mathrm{v}$ ahrotekhnichnykh koledzhakh [Structural-organizational model of future economists' training in agrotechnical colleges]. Ukrainian Journal of Educational Studies and Information Technology, 6 (4), 37-52. Retrieved from http://www.ojs. mdpu.org.ua/index.php/itse/article/view/2485 [in Ukrainian].

4. Krutous, T. P. (2015). Formuvannia fakhovoi kompetentnosti maibutnikh bakalavriv ekonomiky u protsesi navchannia pryrodnychonaukovykh dystsyplin [Formation of the future economics bachelors' professional competence in the process of teaching natural sciences] Candidate's thesis. Vinnytsia : Vinnytskyi derzh. ped. un-t imeni Mykhaila Kotsiubynskoho [in Ukrainian].

5. Mann, R. V. (2018). Deiaki aspekty zastosuvannia informatsiino-komunikatsiinykh tekhnolohii u pidhotovtsi maibutnikh ekonomistiv [Some Aspects of Information and Communication Technologies Application in Preparation of Future Economists]. Informatsiini tekhnolohii $i$ zasoby navchannia - Information Technologies and Learning Tools, 64 (2), 170-184 doi: http://dx.doi. org/10.33407/itlt.v64i2.1933 [in Ukrainian].

6. Naumuk, I. M. \& Korzun, N. I. (2018). Osoblyvosti vykorystannia tekhnolohii dystantsiinoho navchannia $u$ protsesi pidhotovky maibutnikh uchyteliv informatyky [Features of the distance learning technologies' use in the process of training future informatics 
teachers]. Ukrainian Journal of Educational Studies and Information Technology, 6(3). Retrieved from http://ojs.mdpu.org.ua/index.php/itse/ article/view/2482 [in Ukrainian].

7. Osadchyi, V. A. \& Osadcha K. P. (2015). Suchasni realii i tendentsii rozvytku informatsiino-komunikatsiinykh tekhnolohii v osviti [Modern Realities and Trends of Information and Communication Technologies Development in Education]. Informatsiini tekhnolohii $i$ zasoby navchannia - Information Technologies and Learning Tools, 48 (4), 47-57. doi: http://dx.doi.org/10.33407/itlt.v48i4.1252 [in Ukrainian].

8. Stebliuk, S. V. \& Starosta, V. I. (2017). Interaktyvne navchannia $\mathrm{u}$ protsesi pidhotovky maibutnikh fakhivtsiv ekonomichnykh spetsialnostei [Interactive teaching in the process of training future specialists of economic specialties]. Uzhhorod : Vydavnytstvo UzhNU «Hoverla» [in Ukrainian].

9. Stoliarenko, T. L. (2014). Vykorystannia zasobiv IKT u systemi pidhotovky ekonomistiv [The use of ICT tools in the training of economists]. Pedahohichni nauky: teoriia, istoriia, innovatsiini tekhnolohii - Pedagogical sciences: theory, history, innovative technologies, 10 (44), 56-62 [in Ukrainian].

10. Tkach, Yu. M. (2016). Zastosuvannia informatsiinokomunikatsiinykh tekhnolohii $\mathrm{u}$ navchalnomu protsesi $\mathrm{v}$ umovakh fundamentalizatsii profesiinoi pidhotovky maibutnikh ekonomistiv [Application of information and communication technologies in the educational process under the conditions of the future economists' professional training fundamentalization]. Pedahohika formuvannia tvorchoi osobystosti u vyshchii i zahalnoosvitnii shkolakh - Pedagogy of the formation of a creative person in higher and secondary schools, 49(109), 202-212 [in Ukrainian].

11. Measuring the Information Society Report 2017. Retrieved from https://www.itu-ilibrary.org/science-and-technology/measuringthe-information-society-report-2017_ pub/80f52533-9474f7ae-en.

12. Ukraine - Networked readiness index ( $7=$ Best) (2016). Retrieved from https://knoema.com/atlas/Ukraine/topics/WorldRankings/World-Rankings/Networked-readiness-index. 


\section{Вступ}

Інформаційні технології широко впроваджуються у всі сфери життєдіяльності людини і цей процес інтенсифікується, зокрема й в Україні. За даними звітів 2013-2017 pp. «Вимірювання інформаційного суспільства», що підготовлені експертами Міжнародного союзу електрозв'язку (МСE) при $\mathrm{OOH}$, Україна просувається в світовому рейтингу 3 розвитку IT-технологій. За цей період індекс розвитку інформаційнокомунікаційних технологій України зріс з 5,15 до 5,62 (Measuring the Information..., 2017). Індекс мережевої готовності (Networked Readiness Index), що характеризує рівень розвитку інформаційнокомунікаційних технологій країни, також зростав 3 3, 5 (2007 рік) до 4,2 (2016 рік) (Ukraine - Networked readiness..., 2016).

Процес розвитку й розповсюдження IT впливає й на освітню сферу, зокрема на процес професійної підготовки спеціалістів різних галузей. Реформування системи освіти України відповідає загальній тенденції розвитку систем освіти європейських країн, зокрема, як у провідних країнах світу в Україні прийнята Женевська декларація принципів, Женевський план дій, Туніські зобов'язання та Туніська програма для інформаційного суспільства, прийнято низку документів 3 інформатизації освіти, ІКТ-компетентність визначається як одна 3 базових, здійснюється впровадження електронного і дистанційного навчання, здійснюється підвищення кваліфікації вчителів і викладачів у галузі ІКТ, реалізується процес відкритого доступу до інформації. Таким чином, модернізація системи освіти України здійснюється в контексті європейських вимог і спрямована на ті1 інтегрування у європейський i світовий інформаційно-освітній простір (Манн, 2018).

Нині науковцями накопичено значний досвід результатів застосування інформаційно-комунікаційних технологій (IКТ) у професійно-технічній та вищій школі. За останні п'ять років професійній підготовці фахівців засобами IKT присвячена низка досліджень, зокрема: А. В. Литвин та О. Г. Литвин проаналізовано прогностичні напрями інформатизації професійної підготовки, М. І. Садовим та О. М. Трифоновою досліджено процес організації професійної підготовки фахівців 
в умовах хмаро-орієнтованого навчального середовища, В. В. Ткачук висвітлено процес проектування професійних IKTкомпетентностей майбутніх інженерів-педагогів, Ю. В. Вінтюк представлено можливості засоби IKT у підготовці фахових психологів, О. Л. Дишко висвітлено досвід використання віртуальних спільнот для підготовки бакалаврів 3 туризму, B. I. Бобрицькою та С. М. Процькою з'ясовано особливості формування професійних компетентностей майбутніх філологів засобами комп'ютерно орієнтованих технологій, М. І. Шерманом описано дистанційні технології як складову системи комп'ютерноінформаційної підготовки майбутніх екологів, О. Д. Гаврилюк здійснено аналіз використання хмаро-орієнтованих технологій навчання для формування професійних компетентностей майбутніх бакалаврів статистики.

Особлива увага науковців зосереджена на застосуванні IKT у професійній підготовці та перепідготовці педагогів: А. Ф. Верлань, I. Г. Ветрова, Ю. В. Горошко, А. М. Гуржій, А. М. Гура, К. Р. Колос, Л. А. Лупаренко, Л. Л. Макаренко, О. М. Царенко, А. О. Юрченко та ін. Натомість не достатньо уваги приділено проблемі застосування інформаційно-комунікаційних технологій у професійній підготовці майбутніх економістів в Україні.

Метою статті $є$ здійснення аналізу досвіду застосування інформаційно-комунікаційних технологій у професійній підготовці майбутніх економістів, зокрема у закладах вищої освіти (ЗВО) I-II рівнів акредитації в Україні.

\section{Матеріал і методи дослідження}

Для досягнення поставленої мети використовувалися такі згальнонаукові методи: метод вивчення наукових джерел; аналіз, синтез, порівняння та узагальнення.

\section{Результати та їх обговорення}

У процесі дослідження було здійснено аналіз наявності наукових публікацій за темою на основі даних веб-порталу Національної бібліотеки України імені В. I. Вернадського та безкоштовної пошукової системи за повними текстами наукових публікацій у Академії Google.

Пошук у базі даних Національної бібліотеки України імені В. І. Вернадського здійснювався у розділі «Повнотекстовий 
пошук» за такими ключовими словами «IКТ» + «майбутні економісти». У результаті було знайдено 937 релевантних документів. Аналіз, здійснений за допомогою пошукової системи Академія Google, здійснювався за пошуковою фразою «ікт підготовка економістів». У результаті було видано 5520 документів, яких після фільтрації за датою (з 2014 по 2019 роки) залишилося 795. Далі знайдені документи були відфільтровані за такими критеріями: відповідність темі дослідження, реалізація публікації у вигляді наукового дослідження (стаття, автореферат, дисертація), значущість дослідження та вагомість результатів.

Таким чином було проаналізовано 37 робіт, серед яких найбільш значущими, на наш погляд $є$ праці таких науковців: Л. А. Гаврутенко, У. Т. Дудка, Т. Л. Столяренко, Р. В. Манн, С. М. Коноваленко, С. В. Стеблюк, В. І. Староста.

У статті Т.Л. Столяренко проаналізовано засоби інформаційних технологій, що використовуються в процесі професійної підготовки майбутніх економістів, зокрема: Microsoft Office, Visual Basic for Applications, ABBYY FineReader, Acrobat Reader, Інтернет-браузери для роботи 3 сайтами Інтернетаукціонів, фінансових новин та системами створення експертних систем, математичні пакети прикладних програм (Mathcad, Mapl, Matlab, Mathematica, Statistica), засоби інформаційних технологій (комп'ютерні тести, виконання практичних розрахункових задач тощо), програми для автоматизації напрямів господарської діяльності підприємств («1C: Бухгалтерия», «1C: торговля. (Управление торговлей)», «1С: Зарплата и Кадры (управление персоналом)», «1С: Производство (УПП)», «1С: Предприятие (комплексный учет)», «Галактика», «Банківське ситуаційне моделювання», «Парус»). На основі аналізу автор зазначає, що одним iз пріоритетних напрямів застосування інформаційних технологій у навчальному процесі вищої економічної школи виступають системи, що забезпечують оперативний зворотний зв’язок, комп'ютерну візуалізацію навчальної інформації, архівне збереження великих обсягів інформації 3 можливістю легкого доступу користувача до бази даних, автоматизацію процесів обчислювальної, інформаційно-пошукової діяльності, обробки результатів експерименту, автоматизацію процесів 
управління навчальною діяльністю та контролю його результатів (Столяренко, 2014).

Застосування інформаційно-комунікаційних технологій у процесі професійної підготовки майбутніх економістів, як зазначає Ю. М. Ткач, призводить до створення умов для розвитку вмінь i навичок самоосвіти шляхом організації творчо-дослідницької навчальної роботи студентів, спрямованої на інтеграцію знань 3 різних дисциплін, а отже, сприяє фундменталізації їх професійної підготовки майбутніх. Акцентуючи увагу на проблемі фундаменталізації професійної підготовки майбутніх економістів науковець також наголошує, що викладач, який використовує IКТ, має можливість інтенсифікувати навчальний процес, підвищити мотивацію до навчання, оптимізувати та підвищити ефективність навчального процесу, зробити його більш наочним і динамічним (Ткач, 2017:206). Науковець у своєму дослідженні зупиняється на загальних засадах застосування IКТ у професійній підготовці майбутніх економістів та наведенні одного конкретний приклад, a саме використання електронних таблиць Microsoft Exel для вирішення економічної задачі (дослідження залежності ціни автомобіля від таких характеристик як вік авто та обсяг його двигуна на основі вибіркових даних), не надаючи комплексного уявлення про стан $\mathrm{i}$ рівень застосування інформаційнокомунікаційних технологій у підготовці майбутніх економістів.

Т.П. Крутоус найбільш актуальними інноваціями в підготовці студентів ЗВО економічного профілю вважає такі засоби IКТ як мультимедіа, дистанційне навчання, технології «віртуальної реальності», програмно-тестове навчання, спеціалізовані прикладні програми, альбоми унаочнення тощо) (Крутоус, 2015:43-44). На думку дослідниці застосування Інтернет-технологій забезпечує розвиток та формування індивідуальних особливостей майбутніх бакалаврів економіки, таких як: уміння одержувати нову інформацію в предметній області, використовуючи репродуктивну технологію навчання; алгоритмічно й конструктивно мислити на основі досвіду практичного використання програмних продуктів, які грунтуються на репродуктивно-алгоритмічній технології навчання; творчий потенціал у ході виконання евристичних і дослідницьких завдань; 
комунікативні уміння в процесі проектної діяльності й навички прийняття оптимальних рішень у ході ведення експериментів; інформаційна культура (Крутоус, 2015:75-76). Слушними є тези авторки про те, що для впровадження мережевих технологій у професійну підготовку майбутніх економістів найбільш перспективним $є$ використання інформаційного середовища Moodle (Modular Object-Oriented Dynamic Learning Environment модульне динамічне об'єктивно-орієнтоване середовище для навчання). Переваги системи Moodle зумовлені наявністю у ній засобів розробки контенту, підсистем управління освітнім процесом і підтримкою SCORM (англ.: Sharable Content Object Reference Model - набір стандартів та специфікацій, розроблений для систем дистанційного навчання). Наявність локалізації українською мовою, модульність, мультимедійність, відкритість коду забезпечує Moodle високі рейтинги популярності в більшості країн світу, як платформи для дистанційного навчання (Наумук \& Корзун, 2018:75). Також позитивною для широкого застосування в освіті особливістю Moodle $\epsilon$ підтримка сучасних стандартів електронного мережевого навчання та орієнтація на педагогіку конструктивізму, яка передбачає активне залучення студентів у процес формування фахової компетентності та взаємодію між собою (Крутоус, 2015:99).

Як зазначає Р.В. Манн, для підготовки майбутнього висококваліфікованого конкурентоспроможного фахівця економічного профілю ІКТ відіграють важливу роль. На відміну від Т. Л. Столяренко, Ю. М. Такч та Т. П. Крутоус науковець акцентує увагу не лише на використанні мультимедійного забезпечення, офісних технологій та Інтернет-ресурсів, а й симуляційних продуктах у галузях бізнесу, стратегії і менеджмену (Cesim Global Challenge, Cesim OnService, Cesim SimFirm, Cesim Project Cesim SimBrand, Cesim Hospitality, Cesim SimPower, Cesim Connect, Cesim Bank та ін) та програмно-імітаційних комплексах 3 метою проведення конкурсів, змагань чи олімпіад. Це, на думку науковця, дає змогу майбутнім економістам розвивати пошуково-аналітичні здібності, вміння працювати з інформацією, підвищувати свій творчий потенціал та самостійну пізнавальну роботу (Манн, 2018). Науковець грунтовно проаналізував наявні 
інформаційно-комунікаційні технології підготовки майбутніх економістів, окресливши майже всі сучасні здобутки IT-галузі. Проте не описав застосування таких технологій навчання як мобільні та віртуальні.

Більшість проаналізованих наукових праць присвячені висвітленню питань застосування ІКТ у вищій економічній освіті.

У статтях таких науковців як В. Я. Басараб, У. Т. Дудка, Л. А. Гаврутенко, С. В. Стеблюк, В. І. Староста здійснено дослідження впровадження IКТ у ЗВО I-II рівня акредитації при підготовці студентів економічних спеціальностей.

Зокрема У. Т. Дудка за допомогою методу моделювання пропонує структурно-організаційну модель підготовки майбутніх економістів до професійної діяльності засобами IКT, в якій результатом навчання виступає не просто оволодіння студентом системою професійних знань і вмінь, а сформованість готовності до професійної діяльності. На основі моделі ,яка запроваджена в агротехнічному коледжі, авторкою акцентовано увагу на викладанні тих інформатичних понять і категорій, які несуть у собі найбільше фактичне фахове навантаження (Дудка, 2018).

Зазначаючи, що широке застосування IКТ дозволяє реалізовувати особистісно-діяльнісний підхід до підготовки сучасних майбутніх молодших спеціалістів Л. А. Гаврутенко, наголошує на тому, що економічні коледжі активно використовують ІКТ у професійній підготовці для унаочнення, контролю, тренування, пошуку та обміну інформацією тощо. Однак рівень ефективності інформатизації навчальної діяльності залишається досить низьким, не зважаючи на те, що коледжі активно оснащуються комп'ютерними лабораторіями та програмними засобами. Однак, ці дії, як правило, носять несистемний характер; пропоновані програмні засоби призначені для вирішення часткових завдань; засоби IКТ різних підрозділів не взаємоузгоджені. Дослідниця слушно зазначає, що основою професійної підготовки молодших спеціалістів має стати високотехнологічне інформаційно-освітнє середовище економічного коледжу (Гаврутенко, 2017:77).

IКТ як один із засобів реалізації інтерактивного навчання у процесі підготовки майбутніх фахівців економічних 
спеціальностей в коледжах сфери кооперації в Україні визначають C. В. Стеблюк та В. I. Староста. 3 погляду науковців IKT у технологіях інтерактивного навчання має сприяти навичкам спільної роботи, і також реалізації головної мети освіти успішній соціалізації індивіду в суспільстві (Стеблюк \& Староста, 2017:40]. Приділяючи багато уваги інтерактивним технологіям С. В. Стеблюк та В. I. Староста не достатньо розкрили шляхи та можливості застосування ІКТ технологій у професійній підготовці майбутніх економістів у ЗВО I-II рівнів акредитації.

Застосування ІКТ у професійній підготовці не має бути самоціллю. Більшість наукових робіт 3 цієї проблематики присвячено підвищенню мотивації студентів, підвищенню ефективності професійної підготовки, формуванню професійних умінь. Чітка узгодженість простежується між використанням IКТ у професійній підготовці майбутніх економістів та їх ІКТкомпетентністю. Зокрема на цьому наголошує В. Я. Басараб, визначаючи інформаційну компетентність як здатність особистості орієнтуватися в інформаційному просторі, володіти й оперувати інформацією згідно з професійними, особистісними, суспільними та іншими потребами, цього досягають завдяки інтеграції системи знань, умінь і навичок щодо набуття, перетворення, передання й використання інформації, нових інформаційних технологій у різних галузях людської діяльності (Басараб, 2016:50). Автор наголошує, що лише сформована інформаційна компетентність, що дасть змогу ефективно працювати 3 інформацією в усіх формах іiі подання, застосовувати весь потенціал інформаційних i телекомунікаційних технологій у навчальній та майбутній професійній діяльності, для самовдосконалення впродовж життя. (Басараб, 2016:52).

\section{Висновки}

Аналіз досвіду застосування інформаційно-комунікаційних технологій у професійній підготовці майбутніх економістів в Україні на основі наукових праць, знайдених за допомогою пошукових можливостей веб-порталу Національної бібліотеки України імені В. І. Вернадського та пошукової системи Академія Google за останні п'ять років, дозволяють зробити такі висновки: актуальність осмислення результатів впровадження інформаційно- 
комунікаційних технологій у професійну освіту підготовку майбутніх економістів не зменшується; найбільше досліджень присвячено аналізу досвіду і з'ясуванню ролі IКТ у професійні підготовці майбутніх економістів у закладах вищої освіти IIIIV рівня акредитації; наукові праці щодо впровадження IКТ у 3BO I-II рівня акредитації при підготовці студентів економічних спеціальностей висвітлюють окремі аспекти цієї проблеми (підготовка майбутніх економістів до професійної діяльності засобами IKT, IКТ як засіб формування професійних умінь майбутніх молодших спеціалістів економічного профілю у процесі вивчення фахових дисциплін, ІКТ у підтримці інтерактивного навчання майбутніх фахівців економічних спеціальностей, формування ключових компетентностей майбутніх обліковців 3 реєстрації бухгалтерських даних засобами ІКТ). Проте застосування у професійній підготовці майбутніх економістів таких новітніх інформаційних технологій як мобільні, віртуальної та доповненої реальності, «великих даних», блокчейну, адаптивного навчання, а також системи управління навчанням наступного покоління та природні користувацькі інтерфейси українськими науковцями не достатньо розглянуті.

Перспективами подальших розвідок у даному напрямку вбачаємо висвітлення цих питань як у системі 3BO III-IV рівнів акредитації так і ЗВО I-II рівнів акредитації.

\section{Література}

1. Басараб В. Я. Формування ключових компетентностей майбутніх обліковців 3 реєстрації бухгалтерських даних у професійно-технічних навчальних закладах: дис. ... канд. пед. наук: 13.00.04 / ДВНЗ «Криворізький національний університет». Кривий Ріг, 2016. 286 с.

2. Гаврутенко Л. А. Формування професійних умінь майбутніх молодших спеціалістів економічного профілю у процесі вивчення фахових дисциплін: дис. ... канд. пед. наук: 13.00.04 / Національний авіаційний університет. Київ. 2017. 248 с.

3. Дудка У. Т. Структурно-організаційна модель підготовки майбутніх економістів в агротехнічних коледжах. Ukrainian Journal of Educational Studies and Information Technology. Том 6. 
№ 4 (2018). C. 37-52. URL: http://www.ojs.mdpu.org.ua/index.php/ itse/article/view/2485.

4. Крутоус Т. П. Формування фахової компетентності майбутніх бакалаврів економіки у процесі навчання природничонаукових дисциплін: дис. ... канд. пед. наук: 13.00 .04 / Вінницький держ. пед. ун-т імені Михайла Коцюбинського. Вінниця. 2015. 245 с.

5. Манн Р. В. Деякі аспекти застосування інформаційнокомунікаційних технологій у підготовці майбутніх економістів. Інформаційні технології $i$ засоби навчання. 2018. Том 64. № 2. C. $170-184$.

6. Наумук I. М., Корзун Н. I. Особливості використання технологій дистанційного навчання у процесі підготовки майбутніх учителів інформатики. Ukrainian Journal of Educational Studies and Information Technology. Tом 6. № 3 (2018). URL: http:// ojs.mdpu.org.ua/index.php/itse/article/view/2482.

7. Осадчий В. В., Осадча К. П. Сучасні реалії і тенденції розвитку інформаційно-комунікаційних технологій в освіті. Інформачійні технології $i$ засоби навчання. 2015. Т. 48. Вип. 4. C. 47-57. URL: http://nbuv.gov.ua/UJRN/ITZN_2015_48_4_6.

8. Стеблюк С. В., Староста В. I. Інтерактивне навчання у процесі підготовки майбутніх фахівців економічних спеціальностей : навчальний посібник. Ужгород : Видавництво УжНУ «Говерла». 2017. 156 с.

9. Столяренко Т. Л. Використання засобів ІКТ у системі підготовки економістів. Педагогічні науки: теорія, історія, інновачійні технології. 2014. № 10 (44). С. 56-62.

10. Ткач Ю. М. Застосування інформаційно-комунікаційних технологій у навчальному процесі в умовах фундаменталізації професійної підготовки майбутніх економістів. Педагогіка формування творчої особистості у вищій $i$ загальноосвітній школах. 2016. Вип. 49(109). С. 202-212.

11. Measuring the Information Society Report 2017. URL: https://www.itu-ilibrary.org/science-and-technology/measuring-theinformation-society-report-2017_ pub/80f52533-9474f7ae-en.

12. Ukraine - Networked readiness index $(7=$ Best $)$. URL: https://knoema.com/atlas/Ukraine/topics/World-Rankings/WorldRankings/Networked-readiness-index. 
Осадчий В. В.

\begin{abstract}
Анализ опыта применения информационно-коммуникационных технологий в профессиональной подготовке будущих экономистов в Украине
\end{abstract}

\title{
Аннотация
}

Развитие информационных технологий влияет на процесс профессиональной подготовки специалистов различных отраслей. Учеными Украины за последние пять лет был осуществлен ряд исследований по внедрению информационнокоммуникационных технологий в профессиональном образовании. Целью исследования выбрано осуществление анализа опыта применения информационно-коммуникационных технологий в профессиональной подготовке будущих экономистов, в частности в высших учебных заведениях (ВУЗ) I-II уровней аккредитации в Украине. В процессе исследования был осуществлен анализ наличия научных публикаций по теме на основе данных веб-портала Национальной библиотеки Украины имени В. И. Вернадского и бесплатной поисковой системы по полным текстам научных публикаций в Академии Google. В результате было найдено 6457 релевантных документов, которые были отфильтрованы по следующим критериям: соответствие теме исследования, реализация публикации в виде научного исследования (статья, реферат, диссертация), по дате публикации (с 2014 по 2019 годы), значимость исследования и значимость результатов. На основе анализа публикаций были сделаны следующие выводы: актуальность осмысления результатов внедрения ИКТ в подготовку будущих экономистов не уменьшается; большинство исследований посвящено анализу опыта и выяснению роли ИКТ в профессиональной подготовке будущих экономистов в высших учебных заведениях III-IV уровня аккредитации; научные работы по внедрению ИКТ в ВУЗы I-II уровня аккредитации при подготовке студентов экономических специальностей освещают отдельные аспекты этой проблемы (подготовка будущих экономистов к профессиональной деятельности средствами ИКТ, ИКТ как средство формирования 
профессиональных умений будущих младших специалистов экономического профиля в процессе изучения специальных дисциплин, ИКТ в поддержке интерактивного обучения будущих специалистов экономических специальностей, формирование ключевых компетентностей будущих учетчиков по регистрации бухгалтерских данных средствами ИКТ).

Ключевые слова: информационно-коммуникационные технологии, профессиональная подготовка, будущие экономисты.

\section{Осадчий В. В.}

\section{Аналіз досвіду застосування інформаційно-комунікаційних технологій у професійній підготовці майбутніх економістів в Україні}

\section{Анотація}

Розвиток інформаційних технологій впливає на процес професійної підготовки спеціалістів різних галузей. Науковцями України за останні п'ять років було здійснено низку досліджень щодо впровадження інформаційно-комунікаційних технологій у професійну освіту. Метою дослідження обрано здійснення аналізу досвіду застосування інформаційно-комунікаційних технологій у професійній підготовці майбутніх економістів, зокрема у закладах вищої освіти (ЗВО) I-II рівнів акредитації в Україні. У процесі дослідження було здійснено аналіз наявності наукових публікацій за темою на основі даних веб-порталу Національної бібліотеки України імені В. I. Вернадського та безкоштовної пошукової системи за повними текстами наукових публікацій у Академіï Google. У результаті було знайдено 6457 релевантних документів, які були відфільтровані за такими критеріями: відповідність темі дослідження, реалізація публікації у вигляді наукового дослідження (стаття, автореферат, дисертація), за датою публікація (з 2014 по 2019 роки), значущість дослідження та вагомість результатів. На основі аналізу публікацій було зроблено такі висновки: актуальність осмислення результатів впровадження IКТ у професійну освіту підготовку майбутніх економістів не 
зменшується; найбільше досліджень присвячено аналізу досвіду i з’ясуванню ролі IКT у професійні підготовці майбутніх економістів у закладах вищої освіти III-IV рівня акредитації; наукові праці щодо впровадження IКТ у ЗВО I-II рівня акредитації при підготовці студентів економічних спеціальностей висвітлюють окремі аспекти цієї проблеми (підготовка майбутніх економістів до професійної діяльності засобами ІКТ, ІКТ як засіб формування професійних умінь майбутніх молодших спеціалістів економічного профілю у процесі вивчення фахових дисциплін, IКТ у підтримці інтерактивного навчання майбутніх фахівців економічних спеціальностей, формування ключових компетентностей майбутніх обліковців з реєстрації бухгалтерських даних засобами ІКТ).

Ключові слова: інформаційно-комунікаційні технології, професійна підготовка, майбутні економісти. 